\title{
A study of Task-based Language Teaching Strategies in English
}

\author{
Chai Guoxi, Wen Qiaozhi \\ Xijing University, xi`an Shaanxi 710123, China
}

Keywords: English teaching, task-based, teaching strategies

\begin{abstract}
The task-based approach is only written into the new curriculum standard teaching approach, is a match with the concept of the new curriculum standards, teaching ways to contribute to the implementation of the new curriculum standard. It is suitable for various types of activities and organization. TBLT is beneficial to students' all-round development, advocate the perception, experience, practice, participation and cooperation learning. Task based language teaching to create close to the student life situations, to have real significance. Analysis of task-based language teaching, and illustrates the implementation of task-based language teaching.
\end{abstract}

\section{Introduction}

The rapid development of science and technology, the extensive application of information technology, put forward the hitherto unknown challenge to the English teaching. In order to meet the needs of the curriculum reform, English teaching ideas, goals, contents, strategies, methods, evaluation and other aspects to carry out major reforms in English teaching. To seek knowledge and language development, inheritance the tradition and reflection of modern science and technology, the best combination between scientific literacy and humanistic spirit, realize the English learning of life and personality and subjective mastery, strengthen the development of students' English learning.

\section{What is task-based approach?}

Task based teaching is a specific tasks as learning motivation, to complete the task for the learning process, to demonstrate the results of teaching methods to reflect the achievements. The core idea of task-based teaching is the life of people in the use of language are engaged in all kinds of activities through the design of different language learning tasks into the classroom. The language learning and language use in daily life. It can be said that the combination of task-based language teaching is used as the power, for the purpose of application, the teaching approaches for the application as the core, some teachers like to call the "to study and use.

\subsection{The characteristics and significance of Task-based Language Teaching}

\subsubsection{The task-based language teaching is conducive to all-round development of students}

In the task-based language teaching, students are to complete the task through acquisition of language, in the process of completing the task, they need to collaborate with peers, exchange, may also need to complete a work, which is conducive to the students to play smart and mutual cooperation in many aspects, but also conducive to stimulate students' interest in learning and lay the foundation for their lifelong learning.

\subsubsection{Task-based language teaching advocates perception, experience, practice, participation and cooperation learning.}

In the process of completing the task, students usually need to cooperate and communicate with their peers, and the use of existing language knowledge and skills to construct new language knowledge and skills in language practice, mutual exchange and cooperation in the play. 


\subsubsection{Task-based language teaching emphasizes the introduction of authentic language material into Teaching}

Inputting authentic language materials can not only improve students' interest in learning and keep them in the real environment, but also help students to produce idiomatic language while they are finishing their tasks

\subsubsection{The task-based language teaching is open}

The opening of task-based language teaching shows respect for students' personality development. Different students can accomplish their tasks in their own way, and the result of the task can also fully display the students' personality

For example: complete the animal in students' theme, the teacher gave the students a complete homework, a postcard animal production. Students can download online or in the form of his paintings, 4 paintings of animal pictures, and tell the movement of these animal. Such peer learning tasks and broaden their thinking space. Develop their imagination and creativity. You can imagine the children's work is full of playful and colorful, is to promote their individuality. With the new curriculum reform requires teachers to people-oriented, to promote the development of personality education concept agree without prior without previous consultation.

\subsection{Task-based language teaching attaches importance to the meaning of language}

The traditional language teaching too much emphasis on the structure and form of language, ignoring the meaning of language. But the children in the process of learning a foreign language, the expression will not consciously focus on meaning, structure and word sentence spelling. And task-based language teaching allows students to focus and interest on tasks, in line with the characteristics of the children are learning the language, let the students know the real communication in language communication, experience a new language project, and immediately applied to the language practice. So that task-based language teaching takes the language meaning.

\section{Principles of task design}

\section{(1)Situational principle}

The task-based language teaching should establish close contact student life scenes from the students "learning" perspective to design tasks. When designing the task, should pay attention to the creation of the real teaching situation, the learning environment and the reality of students, but also to solve the task solving process and practical problems are similar. Also, teachers should correctly grasp the students' level of understanding existing, to strive to create a variety of situation from different angles, different view of learning tasks, let students solve problems in real tasks, to enhance their learning confidence, stimulate students' learning interest and enthusiasm to participate in classroom learning.

(2) The principle of authenticity

The task that has real meaning, that is close to the various activities in real life. As early as in real life, students need to participate in various activities, to solve all kinds of problems, and dealing with different kinds of people, and the use of classroom teaching in the formal task on these real-life activities process simulation and students through exercise. Complete different kinds of tasks, master the language communicative ability and problem-solving skills, can more clearly recognize the close contact of language learning and their real life and meaning, to better cultivate their learning and using the English language.

(3) The principle of the whole

The receiving task should involve information, processing and transmission process. Sometimes the fusion of the knowledge of other fields) which not only increase the English learning interest, improve students management information and knowledge ability.

(4)The feasibility principle

The feasibility of the principle is that teachers in the design task, according to their language 
ability, physiological and psychological characteristics to design tasks, students can naturally use English in the process of completing the task. We should pay attention to avoid the tedious task too difficult, to enable students to complete the task to use Chinese to communicate.

(5)Comprehensive ability training principle;

The task of design is not only conducive to students' comprehensive ability to use English, but also pay attention to improve their ability of autonomous learning and problem solving.

(6) The evaluation principle

The students after the completion of the task, the general made a tangible non language, such as: the investigation report, watercolor, mail list, handmade products. These are one of the main tasks of learning assessment basis. At the same time the tangible results display and exchange, it is easy for students to see the learning achievement, experience success. To mobilize them to participate in the study and use of active English. Example: the fourth grade students in the completion of self introduction and talk about home address, each for their own design a English name card, and introduce their own name card in the group, finally put all the class name card made mail list.

\section{The introduction of the task}

In English teaching, it is introduced in the process of teaching the most basic step, Russell said: "a good beginning is half the success." can attract students, to stimulate students' interest to produce a good learning motivation. British educator Russell said: "all of the subject matter, should start from the spirit of the enlightenment, the teaching language should be the fuse, shock wave, doping, there is an attractive idea, thinking of the effect of the excited people." Introduction tend to make the classroom become a good classroom atmosphere more active. The appropriate teaching plan is essential for novice and experienced teachers. Although the preparation does not guarantee the success of the class Walked into the classroom, is often better than be taken by surprise in a disastrous lesson is not started. In addition, the students immediately noticed that their teachers are ready or not ready to receive lessons. Teachers' trust and cooperation of students too much.

\section{The implementation of task based Language Teaching}

\subsection{To the main mission of classroom teaching}

Here are the basic steps of Task-based Language teaching:

Warming-up Activities introduces the subject through songs, rhymes, or everyday dialogue

Pre-task stage (teacher is required to complete the task of language knowledge, introduce the task and task implementation steps)

While-task stage (complete several micro tasks, students individual or group form of task chain, namely task cycle; according to the actual situation of teachers play the task of completing the task supervisor and organizer, facilitator and students completed the tasks partner role)

Post-task stage (in the form of group or individual students to report or display task results)

Homework (according to the task of teachers, classroom layout related homework to students individual or group)

\subsection{Taking homework as the leading factor}

Homework is the continuation and deepening of the classroom teaching, we adopt the task-based language teaching in classroom and homework will also design task oriented practice work in the proper writing exercises, to let students related to the theme of the unit or to solve practical problems with the actual life is closely related to the activities, such as in extracurricular Make: a name card; Make a Book of your favourite food Make a fast food menu; accoding to what the pupi Ls like to eat. practice to cultivate students' ability of acquiring, processing and use of information and the ability to solve practical problems in English, so as to make the homework and task-based classroom teaching. 


\subsection{Evaluation with formative evaluation as the main body}

The new curriculum standard pointed out that the main purpose of primary school English teaching evaluation is the learning interest and motivation of students. The evaluation should be the main form of assessment, students usually participate in various teaching activities and cooperative ability as the main basis. Formative assessment is accompanied by the evaluation of learning process continues, he pays attention to the learning process, try to by improving the learning process to improve learning results, an evaluation means it is also a way of learning. The task-based teaching model due to the importance of the process of language acquisition, provided a stage for the teachers' evaluation to students of science. For example, teachers will be able to complete all kinds of students in the classroom by micro tasks The stars or sub unit sticker accumulated, and the stage of feedback, so that teachers and students know their learning status, promoting students' progress.

\section{Conclusion}

In the process of teaching, I have been through body language, verbal praise, group evaluation of fish spit bubble; through the mutual evaluation between students, through the formative evaluation of students, let students experience the joy of success in the classroom, get ahead of the power to share the fruits of success of cooperation, learning English fun.

In the "task based teaching" multi-dimensional interaction under the guidance of the concept, I cleverly designed above teaching, to achieve the "leading and the main body, and material life, harmonious interaction" double base and innovation, to achieve the "active learning, effective learning, shared learning, innovative learning" teaching realm.

\section{References}

[1] Yuan Zhenguo. Research on policy support system for quality education. Shandong Education Press, 2004 (10).

[2] Wang Yingjie. China's education development report: development of higher education, problems and countermeasures. Beijing Normal University press, 2005 (12).

[3] Alexander, L. G. 1973. Developing Skills New Concept English [M]. Shanghai Foreign language Education Press.

[4] Brown, H.D. 1980. The Optional Model of SLA [J]. TESOL Quarterly. 14: 64-157.

[5] Gardner, R.C. \& W. E. Lambert. 1959. Motivational Variables in Second Language Acquisition. Canadian Journal of Psychology. 13: 266-272.

[6] Gardner, R. \& W. Lambert. 1972. Attitude and Motivation in Second Language Learning. Rowley, Mass.: Newbury House.

[7] Gardner, R. C., R. N. Lalonde, R. Moorcroft \& F.T. Evers. 1985. Second Language Attrition: The Role of Motivation and Use. London, Ontario: University of Western Ontario, department of Psychology.

[8] Gardner, R. C., A. M. Masgoret, J. Tennan \& L. Mihic. 2004. Integrative motivation: Changes during a year-long intermediate-level language course. Language Learning 54/ 1: 1234. 